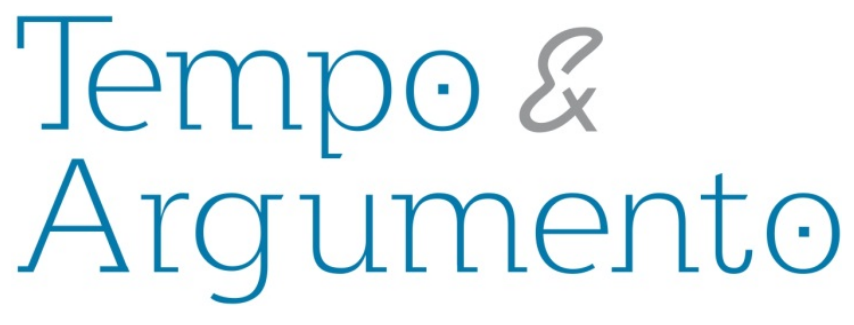

\title{
Memórias de um massacre: violência em A Guerra dos Pelados (Sylvio Back, 1971)
}

\begin{abstract}
Resumo
Em 1971, no contexto dos anos de chumbo da ditadura civil-militar brasileira, o cineasta Sylvio Back lançou o seu segundo filme de longa-metragem, A Guerra dos Pelados, que versa sobre o Movimento do Contestado. A tônica do filme é pessimista e representa a opressão e o massacre sofridos pela comunidade de posseiros, tanto por parte dos fazendeiros locais, quanto pelas autoridades militares. Com tal obra, ao mesmo tempo em que edificava uma memória sobre o passado histórico brasileiro, Back posicionava-se frente às questões do seu tempo. $O$ filme carrega uma ambiguidade bastante significativa ante seu contexto de produção, no que concerne à relação entre os grupos resistentes e a imposição do poder militar por meio do uso da violência. Partindo dessa relação metafórica entre o filme histórico e o seu tempo de produção, este artigo discute as formas de figuração da violência no filme, considerando que essas situações se distinguem por sua função dentro do enredo: algumas vezes, a violência é utilizada como instrumento de coerção, visando garantir a manutenção do poder e o predomínio das formas de dominação e exploração; noutras, a violência pode surgir como instrumento revolucionário, buscando transgredir as relações de poder que se arraigaram.
\end{abstract}

Palavras-chave: BACK, Sylvio - 1937. Cinema e História. Brasil - História - Campanha do Contestado, 1912-1916. Violência.

\section{Para citar este artigo:}

KAMINSKI, Rosane. Memórias de um massacre: violência em A Guerra dos Pelados (Sylvio Back, 1971). Revista Tempo e Argumento, Florianópolis, v. 9, n. 21, p. 153 - 180. maio/ago. 2017.

DOI: $10.5965 / 2175180309212017153$

http://dx.doi.org/10.5965/2175180309212017153 


\title{
Memories of a massacre: violence in A Guerra dos Pelados (Sylvio Back, 1971)
}

\begin{abstract}
The filmmaker Sylvio Back released the film A Guerra dos Pelados in 1971, during the Brazilian civil-military dictatorship. The film deals with the Contestado Movement, a land ownership conflict that occurred in southern Brazil between 1912 and 1916. A Guerra dos Pelados is a pessimistic film that emphasizes the peasants massacre. The peasants' oppressors were landowners and military authorities. The film builds a memory about the history of Brazil, but it also refers to the dictatorship years through the conflicts between opposition groups and military violence. Based on the metaphorical relationship between historical film and social context, this paper interprets the film's violence scenes. In this way, these scenes have several narrative functions: on the one hand, the violence is an instrument of coercion and maintenance of domination and exploitation; on the other hand, it is a revolutionary instrument used to transgress social norms.
\end{abstract}

Keywords: BACK, Sylvio - 1937. Cinema and History. Brazil - History - Contestado Campaign, 1912-1916.

Violence.

1. O filme, a memória, a história

A arte da memória, ou "arte da leitura de cicatrizes" (SELIGMANN-SILVA, 2003, p. 56), não existe fora da linguagem. Nesse sentido, ainda que adentrando os terrenos do ficcional, os filmes históricos são, muitas vezes, assim como a literatura, uma forma encontrada para constituir e preservar memórias sobre eventos traumáticos, que resistem à representação'.

\footnotetext{
1 Baseio-me, aqui, na definição de trauma enquanto evento que resiste à representação, conforme apresentada por SELIGMANN-SILVA, 2003, p. 373; e SELIGMANN-SILVA, 2000, p. 84-87. Também concordo com esse autor quando diz que a linguagem consiste em "máquina não tanto de 'representar' o 'real', mas sim de dar uma forma a ele" (2003, p. 372).
} 
Mas por que lembrar? Nietzsche e Benjamin já teceram os seus elogios ao esquecimento, indicaram os valores tanto do saber "esquecer na hora certa" quanto do “recordar na hora certa”, ainda que não possamos controlar nossa memória². No entanto, "a leitura estética do passado é necessária", ela está "vinculada a uma modalidade da memória que quer manter o passado ativo no presente" (SELIGMANNSILVA, 2003, p. 57).

Nesse sentido, a intenção deste texto é analisar algumas sequências do filme $A$ Guerra dos Pelados, produzido por Sylvio Back entre 1970 e 1971, buscando interpretar as formas pelas quais o cineasta edifica uma memória sobre um evento histórico traumático, ao mesmo tempo em que problematiza o seu tempo presente ${ }^{3}$.

Sylvio Back estreou como diretor de longas-metragens em 1968, com a produção de Lance maior, um filme urbano que aborda as vicissitudes sociais de uma cidade em processo de modernização ${ }^{4}$. A Guerra dos Pelados foi o seu segundo longa-metragem, e um empreendimento ousado: trata-se de filme histórico sobre o Movimento do Contestado, cujo roteiro foi baseado no romance Geração do Deserto (1964), de Guido Wilmar Sassi, acrescido de pesquisa documental e realização de entrevistas com sobreviventes do conflito.

O Contestado foi um conflito pela posse da terra ocorrido na região Sul do Brasil entre 1912 e 1916. Envolveu a expropriação de terras às margens do Rio do Peixe para a construção da estrada de ferro que ligaria São Paulo ao Rio Grande do Sul (cuja empresa concessionária responsável pela exploração da linha por 90 anos era a Brazil Railway, formada por capitais norte-americanos, ingleses e franceses), e também a exploração da madeira neste local pela Southern Brazil Lumber and Colonization (serraria subsidiária da Brazil Railway e constituída justamente para a exploração das terras marginais adquiridas

\footnotetext{
${ }^{2}$ No capítulo intitulado Reflexões sobre a memória, a história e o esquecimento, Seligmann-Silva (2003) menciona o texto "Dos usos e desvantagens da história para a vida", de Nietzsche e o "Experiência e pobreza" de Walter Benjamin para refletir sobre o esquecimento e sobre o aspecto seletivo da memória.

${ }^{3}$ Quanto ao filme histórico que "fala" das questões do presente, sugiro: SORLIN (1977 e 1984); e RAMOS (2002).

${ }^{4}$ Sylvio Back, filho de imigrantes, nasceu em 1937 em Blumenau-SC, e transferiu-se para Curitiba-PR em 1957. Ali, atuou como jornalista e crítico de cinema, iniciando na direção cinematográfica em 1962. Desde 1987, reside no Rio de Janeiro-RJ. Realizou, até hoje, 38 filmes, entre curtas, médias e longas-metragens. Além de cineasta, é escritor e poeta.
} 
na concessão). A região era habitada por sertanejos que mantinham um reduto messiânico de caracterização religiosa bastante complexa, os quais foram expropriados e expulsos daquelas terras. No entanto, motivados pela fé e organizados à espera da promessa milenarista, os sertanejos resistiram às ordens para abandonar o local. Devido à sua resistência, passaram a ser constantemente atacados pelos jagunços dos coronéis e da madeireira internacional, bem como das polícias, o que os instigou a se organizarem também militarmente, afrontando os exploradores. As tensões se exacerbaram e o Exército Federal interveio, quando então ocorreu um quase completo extermínio dos camponeses 5 .

Antes da publicação do romance histórico de Guido Wilmar Sassi, algumas poucas pesquisas acadêmicas haviam sido realizadas sobre o Movimento do Contestado. 0 trabalho mais aprofundado era o de Maria Isaura Pereira de Queiroz, La "Guerre Sainte" au Brésil. Le mouvement messianique du "Contestado", resultante de uma pesquisa de doutorado defendida na Universidade de Paris em 1955 e publicada pela USP em $1957^{6}$. Também havia sido publicado, em 1960, o estudo de Oswaldo Rodrigues Cabral (1979), intitulado João Maria - Interpretação da Campanha do Contestado ${ }^{7}$. Outra obra importante era a de Rui Facó, de 1963, Cangaceiros e fanáticos: gêneses e lutas, muito bem documentada e com uma perspectiva importante sobre as potencialidades do movimento rebelde do Contestado. Lançado em 1964, o romance de Sassi se situava, portanto, entre os primeiros esforços em resgatar as particularidades e constituir uma memória sobre um evento que ainda não era muito difundido na historiografia brasileira. Este resgate ocorreria mesclado à ficção, pois a história foi romanceada e muitos dos personagens de Geração do Deserto são fictícios.

Na ocasião em que Back decidiu produzir o filme A Guerra dos Pelados, segundo contou, ele e o jornalista Oscar Milton Volpini (que participou da adaptação do romance para o roteiro fílmico) ficaram fascinados com o romance de Sassi, e enxergaram nele uma “típica organização cinematográfica por trás das cenas e dos personagens, no

\footnotetext{
${ }^{5}$ Para maiores informações históricas sobre o evento, sugiro: MACHADO, 2004; GALLO, 1999 e RODRIGUES, 2008.

${ }^{6}$ Na ocasião, foi publicada no Boletim no 187 da FFLCH da Universidade de São Paulo, de 1957.

7 Esse livro foi republicado pela Editora Lunardelli (Florianópolis) em 1979, com o título A Campanha do Contestado.
} 
tratamento e no encadear situações dramáticas e históricas". Decidiram, assim, levá-lo às telas de cinema (BACK, 2008, p. 108).

Desde o lançamento do livro de Sassi até produção do filme de Back, ou seja, num período de seis anos, outras pesquisas sobre o Contestado foram publicadas, entre as quais o importante livro de Vinhas de Queiroz (1981) intitulado Messianismo e conflito social. A guerra sertaneja do Contestado: 1912-1916, editado pela primeira vez em 1966, e que também se tornou referência importante para Back e Volpini (BACK, 1986, p. 32). Outro aporte utilizado para elaborar o filme foi um artigo de Walmor Marcelino escrito em 1968, no qual o autor tenta trazer para o seu "presente" os ensinamentos da Guerra Camponesa, ao afirmar: “hoje só há uma força revolucionária: as massas populares, o operário e o camponês. [...] Os camponeses do Contestado perderam a longa guerra por Ihes faltar unidade ideológica e o conhecimento da realidade brasileira" (MARCELINO, 1968, p. 148).

Essas discussões sobre a força revolucionária das massas populares, sobretudo as rurais, ganhavam força nos anos 1960, inclusive no interior da Ação Popular, grupo de esquerda do qual Back fazia parte desde 1967, muito provavelmente devido à amizade pessoal que mantinha com Walmor Marcelino ${ }^{8}$. Tais debates entre grupos de esquerda no Brasil eram coerentes com a disseminação das ideias de libertação pela violência, em partes inspiradas no livro Os condenados da terra, publicado em 1961 por Franz Fanon, um ensaísta marxista francês nascido na Martinica, de ascendência francesa e africana. Ele dizia, acerca dos processos de descolonização: "este mundo estreito, semeado de interdições, não pode ser reformulado senão pela violência absoluta" (FANON, 1968, p. 27).

\footnotetext{
8 Em entrevista concedida à autora, Sylvio Back (2003) afirmou ter participado da Ação Popular aproximadamente entre 1967 e 1970. Essa organização já existia no Brasil desde o começo da década, tendo surgido de uma dissidência da Juventude Universitária Católica (JUC), quando Aldo Arantes, eleito presidente da UNE, deixou a JUC em decorrência de atritos com o cardeal Jaime Barros Câmara. Aos poucos, os estudantes dissidentes iniciaram a formação da Ação Popular, mais precisamente em 1962, por meio da UNE Volante. (RIDENTI, 2002, p. 214-227). Entre meados de 1966 e 1967, reconstituía-se um dos núcleos da AP Curitiba (Ibidem, p. 235), no qual Back ingressaria muito provavelmente por meio da amizade pessoal com Walmor Marcelino, este um dos dirigentes da AP regional. Sobre a organização do núcleo da AP em Curitiba, sugiro: DIAS, 1999; e também o livro no qual Walmor Marcelino (2005) registra algumas de suas memórias sobre aqueles anos.
} 
Nesse livro, Fanon discutiu a violência que presidiu a instauração do mundo colonial e alertou para os mecanismos de dominação usados nos processos de colonização, internalizados pela linguagem e pelas práticas culturais. Abordou a função da violência nas lutas por libertação nacional, sugerindo a necessária reação dos colonizados frente aos colonizadores, afirmando que a "descolonização é sempre um fenômeno violento" (FANON, 1968, p. 25), ou sugerindo “a intuição que as massas colonizadas têm de que a sua libertação deve efetuar-se, e só pode efetuar-se, pela força” ( FANON, 1968, p. 56). Vale lembrar que Franz Fanon, além de ensaísta e filósofo, era um psiquiatra atuante nos hospitais do exército francês na Argélia e, em sua vida profissional, analisou as consequências psicológicas da colonização, tanto para o colonizador quanto para o colonizado.

O livro de Fanon foi prefaciado por Jean-Paul Sartre, que destacou a necessidade de combate pela libertação a partir da luta no campo, inflando o discurso do psiquiatra:

No fogo do combate, todas as barreiras interiores devem derreter-se, [...] todos têm de se alinhar nas posições das massas rurais, verdadeiro reservatório do exército nacional e revolucionário; nas regiões cujo desenvolvimento foi deliberadamente sustado pelo colonialismo, 0 campesinato, quando se revolta, aparece logo como a classe radical: conhece a opressão nua, suporta-a muito mais que os trabalhadores das cidades. [...] Eis o que Fanon explica a seus irmãos da África, da Ásia e da América Latina: realizaremos todos em conjunto e por toda a parte $o$ socialismo revolucionário ou seremos derrotados um a um por nossos antigos tiranos. (SARTRE, in FANON, 1968, p. 7. Grifos meus)

O prefácio escrito por Sartre e o primeiro capítulo do livro Os condenados da terra, intitulado Da violência, foram amplamente lidos pelas gerações jovens em diversos países ${ }^{9}$. Tais palavras ecoavam entre intelectuais e grupos de esquerda que aderiam às ideias de luta armada. Isso resultou num fenômeno que, ainda naquela década, geraria preocupações à Hannah Arendt (1994) sobre o que ela nomeou como "glorificação da violência" por parte das esquerdas.

\footnotetext{
9 Os outros capítulos do livro de Franz Fanon tratam da noção de "consciência nacional" e da concepção de cultura nacional proposta pelo autor. O último capítulo, Guerra colonial e perturbações mentais, trata das "perturbações mentais nascidas da guerra de libertação nacional empreendidas pelo povo argelino" (FANON, 1968, p. 211). Segundo ARENDT (1994, p. 96), apenas o primeiro capítulo do livro foi amplamente lido.
} 
Naqueles anos, como resume André Duarte (1994, p. 81-82), se assistia a rebelião estudantil em todo mundo, os confrontos raciais nos Estados Unidos, a glorificação da violência pelos militantes de esquerda, o aumento surpreendente do progresso tecnológico inclusive no que concerne à produção de meios de violência, o temor da guerra nuclear, a guerra do Vietnã; o desgaste das democracias "sob o império das máquinas burocrático-partidárias", a brutalidade das polícias, entre outras. E foi naquele contexto, enquanto jovens ativistas em todo o mundo tomavam os textos de Sartre e de Franz Fanon como base para justificar seus atos violentos, que Arendt observou uma mudança rumo à violência no pensamento dos revolucionários.

Foi entre 1968 e 1969 que Hannah Arendt escreveu e publicou o livro Sobre a Violência, no qual traçou uma distinção bastante cuidadosa entre "poder" e "violência", termos que são frequentemente enleados. A filósofa afirmou que "a violência constitui-se como o contrário do poder, pois ela é antes um instrumento do que um fim" (ARENDT, 1994, p. 44). Em Arendt, o poder não é atributo de um indivíduo, mas só existe enquanto força de coesão de um grupo. Para existir poder, é preciso haver consenso e, a partir deste, o grupo empossará alguém - no qual reconhece autoridade - para agir em seu nome.

Neste sentido, para essa autora, o poder é um fim, e a violência um instrumento. Os implementos da violência são geralmente usados com o propósito de multiplicar o “vigor" de um indivíduo ou governo. Mas esse "vigor” difere de poder, pois o poder está baseado no apoio, e não nos meios de violência de que dispõe. Entretanto, ainda que seja comum a "combinação de violência e poder", dificilmente encontrados em forma pura, Arendt afirma que o aumento da violência diminui o poder, visto que são opostos: "a violência aparece onde o poder está em risco, mas, deixada a seu próprio curso, ela conduz à desaparição do poder" (ARENDT, 1994, p. 44). Sua grande preocupação, diante da constatação dessa "glorificação da violência" pelas novas esquerdas nos anos sessenta, era que se tomasse a violência por algo mais do que um instrumento, incapaz, portanto, de constituir a essência do poder.

Arendt referiu-se à obra Os condenados da terra, de Fanon, como exemplo da "glorificação da violência" por ter sido uma leitura disseminada entre aquela geração 

conduz à derrota do movimento em poucas semanas" (ARENDT, 1994, p. 96).

A assim chamada "glorificação da violência" se espraiou também pela América Latina, e isso coincidiu com o tempo de produção dos primeiros filmes de Sylvio Back. O Brasil experimentava, naqueles anos, as mais diversas tensões no interior de um regime em que a ditadura de direita, apoiada pelo capital internacional, sustentava um projeto de modernização, e contra a qual as esquerdas desejaram reagir, sobretudo, com armas. A presença dos temas do poder e da violência em A Guerra dos Pelados é, portanto, bastante significativa e, em certa medida, alegórica frente ao seu próprio tempo.

Com a realização do filme, enquanto participava da edificação de uma memória sobre um evento até então pouco discutido na historiografia brasileira ${ }^{10}$, Back posicionava-se frente às questões do seu tempo através da problematização desses fatos passados. A luta pela posse da terra, a guerrilha no campo, o piquete na madeireira, tudo isso acontecera efetivamente no passado histórico brasileiro, mas agora era levado às telas sob a perspectiva de Back.

Como antes dito, o cineasta estava envolvido com a Ação Popular que, desde 1968, vivia a sua fase maoísta ${ }^{11}$. O pensamento maoísta esteve intensamente presente na rearticulação desse organismo de esquerda, insistindo que "o centro de gravidade da revolução, mediada pela estratégia da guerra popular prolongada, deveria ser o campo" (DIAS, 1999, p. 7). Ou seja, a ênfase na luta armada a partir do campo parecia estar em consonância com as ideias difundidas pela leitura dos textos de Fanon e de Sartre. Tratar da resistência armada na região do Contestado num momento como aquele, em que o Brasil vivia uma ditadura de direita, e Back estava envolvido com a esquerda, poderia

\footnotetext{
${ }^{10}$ Até então, o movimento do Contestado era visto como um episódio da história regional. Uma das ambições de Back, com o filme, era a de ampliar a sua visibilidade por meio do cinema.

${ }^{11}$ No decorrer daqueles anos, a fundamentação ideológica da AP passou por uma série de reorganizações, e a partir de 1968, o maoísmo aparecia como uma nova influência que enfatizava a necessidade da luta armada. Sobre a evolução ideológica da AP e as suas diferentes fases ao longo dos anos 1960 e 70, ver: RIDENTI, 2002, p. 213-267.
} 
sugerir sangue novo à ideia de revolução, tão cara ao Brasil dos anos $1960^{12}$. Mas não foi esse o enfoque dado à história no filme A Guerra dos Pelados, pois a interpretação alegórica que o cineasta fez da guerrilha foi pintada com as cores do fracasso. Nessa narrativa, a violência tem papel preponderante.

Na sequência deste artigo, enfim, a ênfase da análise recairá sobre a representação dos usos da violência, seja por parte das autoridades, seja por parte dos colonos posseiros, nas situações de enfrentamento social. No âmbito diegético, tratavamse dos camponeses que ocupavam a região de Taquaruçu-SC e resistiam à tomada das terras em 1913. Num contexto mais amplo, a resistência dos posseiros no filme pode ser interpretada como metáfora da resistência de grupos armados contra a ditadura militar, devido à desigualdade de forças. O posicionamento emblemático do filme se faz ver, em partes, pelas relações entre o assunto escolhido e o que vem se passando no momento histórico em que foi produzido. Mas não se trata apenas disso. A postura do autor também precisa ser balizada pelo modo como ele narra essa história.

No caso de A Guerra dos Pelados, uma característica interessante da narrativa, e que ajuda a traduzir uma visão pessimista de Back acerca da história, é a estruturação do filme em duas fases assimétricas.

Durante toda a primeira parte do filme, a comunidade dos sertanejos mostra-se coesa e fortalecida pela fé no falecido monge São José Maria e na santidade da personagem Ana (Dorothée-Marie Bouvier). Ana é uma jovem médium, virgem e considerada santa pelo grupo, o que parece ser o fator responsável pela coesão dos chamados "pelados" na narrativa fílmica. Nesse trecho, apesar de portarem armas (alguns rifles, facões e espadas de pau), os pelados se mantêm pacíficos. A violência é praticada apenas pelos jagunços e coronéis contra os sertanejos, como instrumento de opressão assegurador do sistema coronelista no sertão catarinense, o que será discutido no próximo tópico. No entanto, os coronéis se referem aos "caboclos" como

\footnotetext{
${ }^{12}$ Revolução é aqui entendida num sentido moderno de uma "mudança da sociedade", ou do anseio pela "transformação radical das condições sociais" (ARENDT, 2011, p. 49 e p. 52). No contexto específico do Brasil dos anos 1960-70, a revolução almejada pelas esquerdas é entendida enquanto luta pela transformação social, com vistas a minimizar as diferenças de classe e a exploração econômica. Para maiores informações sobre os fatores implicados no florescimento de diversas versões do pensamento revolucionário no Brasil dos anos 1960, sugiro: RIDENTI, 2000, p. 33-42.
} 
vagabundos, bandidos e desordeiros, justificando que a violência exercida sobre eles é necessária, enquanto disciplina e manutenção da ordem vigente, pois, como diz um “coronel”: “-com gente dessa laia, é só no laço!”.

Do lado dos posseiros, a frase que os identifica é: “- Somos de paz e devoção”. Ao longo do filme, essa mesma frase é emitida num momento por Adeodato (líder militar dos sertanejos, encenado por Átila lório) e noutro por Pai Velho (líder religioso, vivido por Jofre Soares), para qualificar a comunidade dos pelados.

Na continuidade do filme, quanto mais se acirra a expropriação de terras na região do Contestado, o grupo dos pelados se prepara para reagir com violência. Passam a ser encarados como ameaça séria, e os coronéis convocam a presença de autoridades militares.

A ruptura para uma segunda fase ocorre quando a jovem Ana abdica da sua condição de "santidade". Prefere entregar-se ao romance com o seu guarda-costas. A partir daí, em todo o restante do filme, observa-se o gradual declínio nas forças e na união dos Pelados, até seu quase aniquilamento pelos coronéis e forças militares. A cena final mostra um grupo de sobreviventes se deslocando para o município vizinho, após o massacre sofrido.

As sequências aqui escolhidas para análise são aquelas em que ocorre a figuração da violência, tanto na primeira quanto na segunda parte do filme. Tais situações se distinguem por sua função distinta dentro do enredo: às vezes como opressão, noutras como forma de resistência e libertação, como sugerira Franz Fanon.

\section{A violência como instrumento de coerção}

Nas primeiras imagens do filme A Guerra dos Pelados, ainda no prólogo, uma câmera inquieta mostra uma cerca de arame farpado em pormenor. Ao mesmo tempo, ouve-se o andar de cavalos que se aproximam. No canto superior direito, surge uma legenda com a indicação de tempo e lugar em que se passa o fato: "Taquaruçu, 1913 (interior de Santa Catarina)". 
Enquanto isso, inicia um aviso radiofônico sobre a desapropriação de terras numa faixa de $15 \mathrm{~km}$ ao longo das margens do rio do Peixe. Os capangas que chegam a cavalo investem sobre o grupo de camponeses que trabalha na terra. Um homem uniformizado, à frente dos outros, diz: “- Vocês foram avisados", e dá ordem para que os demais avancem sobre os trabalhadores com a cerca de arame. Um caboclo reclama seu direito às terras, ao que o homem retruca: “- Fala de macho, é?”

O plano seguinte mostra o corpo do caboclo pendurado de ponta cabeça, ao mesmo tempo em que inicia um som percussivo. Outros planos curtos fornecem vistas de corpos de homens e mulheres que pendem de uma árvore, mortos, enquanto uma voz chorosa inicia um canto, cujo ritmo é marcado pela percussão irregular que pontua a composição musical feita por Sergio Ricardo para esta cena do filme:

Peço pouco dessa vida

Prá minha felicidade

Uma caboclada distorcida

Uma viola bem sentida

Facão, mate e liberdade.

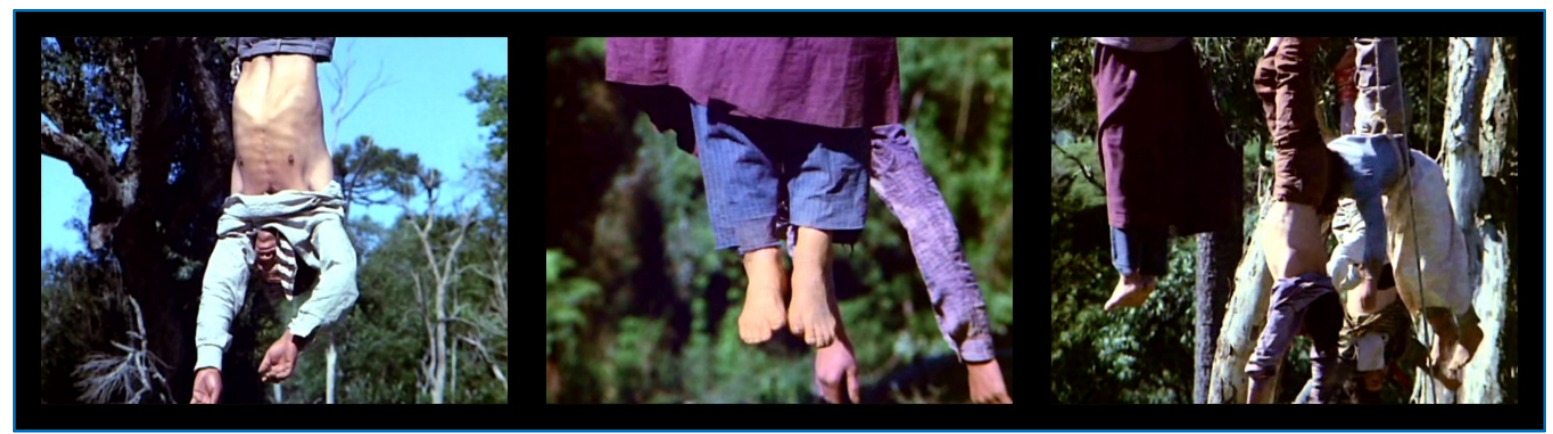

FIGURA 1: Caboclos mortos em A Guerra dos Pelados - função de exemplaridade. A Guerra dos Pelados, 1971.

O tratamento é elíptico: a execução dos atos violentos não foi mostrada pela câmera. Contudo, o efeito simbólico pela exibição das "provas" da violência, ou seja, dos corpos, já é suficiente para evocar todo o terror associado à imagem da "árvore da morte", presente em lendas e em representações de atrocidades de guerra, como nas gravuras da série dos Desastres, de Goya. Os corpos pendentes ficam lá expostos, como "lição" para aterrorizar, garantindo que outros camponeses não queiram burlar as regras dos coronéis, e nem o acordo de concessão de terras entre governo federal e investidores estrangeiros. 


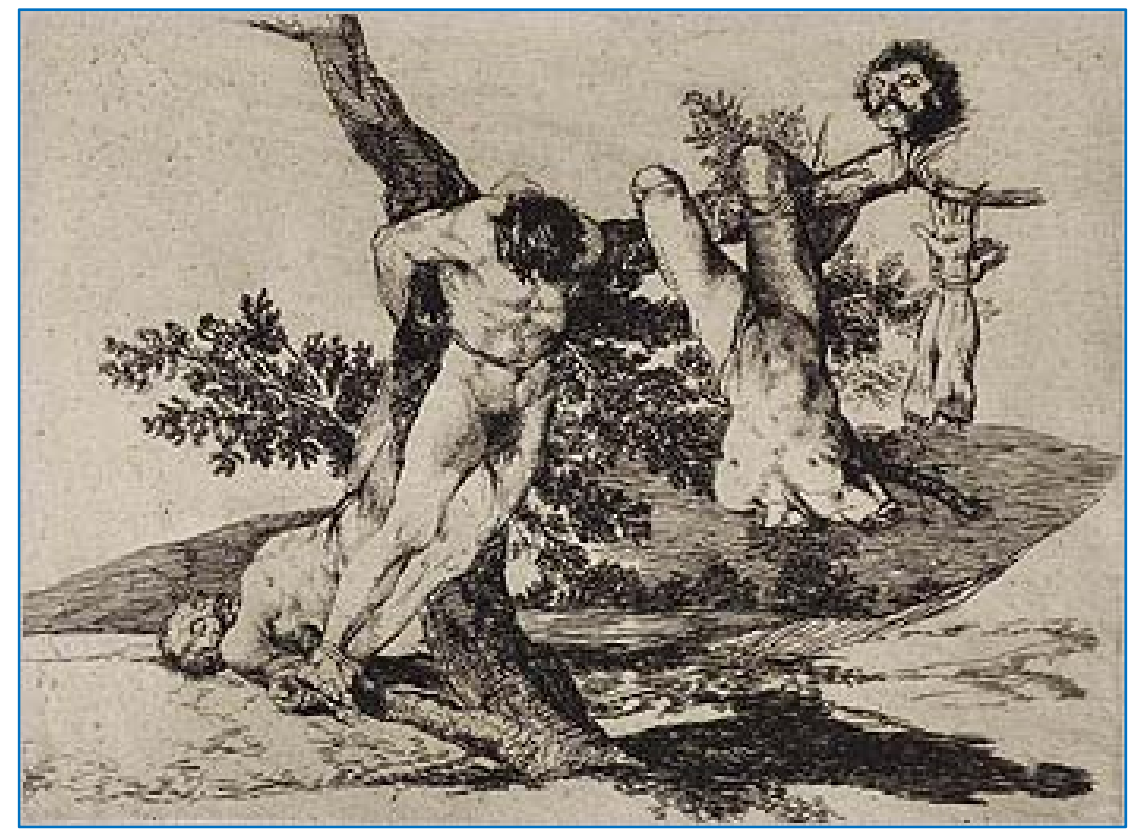

FIGURA 2: Gravura n 39 da série Desastres da Guerra, Francisco de Goya (1810-1815).

Essa cena dos corpos na árvore, já no prólogo do filme, aparece como violência “disciplinadora”, por assim dizer, que se justificaria do ponto de vista do poder oficial preocupado em garantir a ordem e o progresso no local.

Num momento mais avançado do filme, outra cena de violência com função de exemplaridade é a do espancamento dos caboclos. É a mais intensa representação de violência dentro do filme. Não por acaso, foi cortada pela censura da ditadura Médici. Sylvio Back (2008, p. 112-113) conta que:

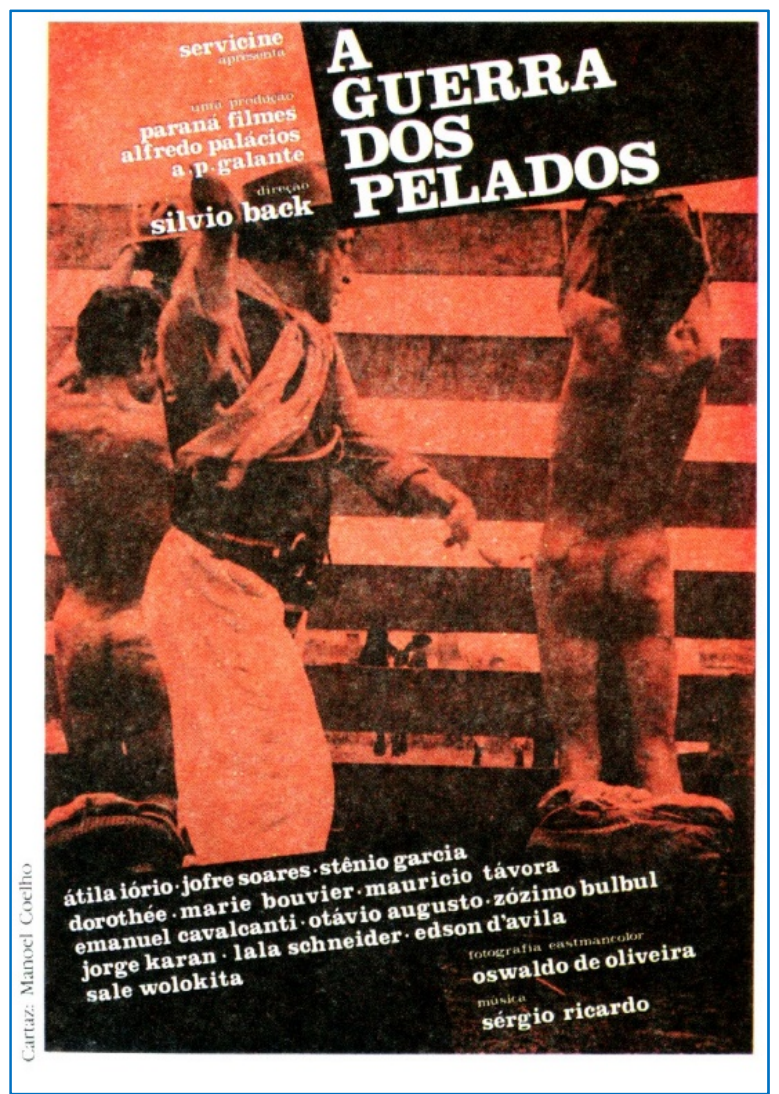

FIGURA 3: Cartaz do filme A Guerra dos Pelados. Manoel Coelho, 1971 
O filme pernoitou em Brasília por mais de seis meses: os censores se dividiam entre proibi-lo pura e simplesmente ou liberá-lo com cortes. [...] Depois de um silêncio atroz, só quebrado por esparsas notícias sempre oficiosas e as mais lúgubres, fomos ansiosos ler o verso do ansiado certificado de censura. Eram três cortes cirúrgicos na imagem e no som: o primeiro mandando extirpar a cena em que um 'coronel' surra na bunda desnuda dois jagunços com vara de marmelo (enquadração que, por sua aura esteticamente simbólica, acabou impondo o mote visual do cartaz do filme, de autoria do premiado arquiteto e designer paranaense, Manoel Coelho).

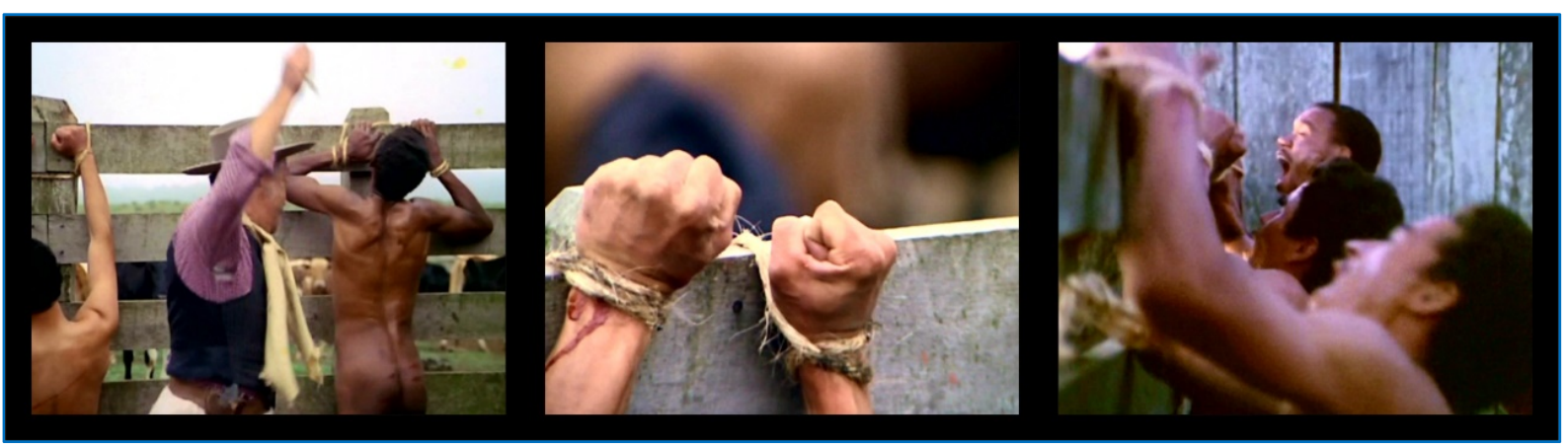

FIGURA 4: Coronel Tidico castiga os pelados. A Guerra dos Pelados, 1971.

A cena da surra acontece logo depois de uma conversa entre o Capitão do exército (Maurício Távora) e a liderança camponesa. Apesar de dizer que também não concordava com a exploração que as companhias estrangeiras vinham fazendo na região, o Capitão aconselhou aos pelados que se retirassem do local "antes que fosse tarde".

A sequência seguinte ao "conselho" dado pela autoridade militar, mostra o espancamento com vara. O enquadramento, a princípio, mostra somente o rosto contraído do “coronel” Tidico (Edson D’Ávila) que golpeia com a vara, e apenas ouvimos os berros do primeiro agredido. O plano seguinte mostra-nos o contexto de outro ângulo. Amarrados pelas mãos à cerca de um curral, estão três homens nus, de costas para o espectador. Um deles apresenta marcas das varadas. O do meio está sendo violentamente agredido por Tidico, se contorce e grita enquanto apanha. Logo chega a vez do terceiro, que também se põe aos berros. A cena é muito incômoda, pela literalidade da representação da violência, e a câmera, como se não quisesse "ver", gira para a direita, passando por uma parede, até enquadrar um grupo de homens que assiste à surra. Capta as expressões dessas testemunhas, que variam entre diversão e o constrangimento. Um deles chega a imitar os gestos de Tidico, golpeando o ar, enquanto 
continuamos a ouvir o barulho das investidas com a vara e os gritos dos desgraçados. Por fim, um plano em plongée nos faz ver o rosto atormentado de um dos homens castigados. Enquanto surra, Tidico diz: “- Mal-agradecido! Pelado sem-vergonha! Pensa que é dono do mundo?..." E continua a esbravejar contra os pelados, enquanto se vê alguns pormenores nos músculos contraídos dos que apanham e já pedem clemência, no sangue em seus pulsos amarrados, nos seus pescoços arfando, e no rosto de um dos vaqueanos que não aguenta mais assistir a cena, preferindo baixar os olhos.

Tidico parece estar completamente fora de si, envolto no deleite da violência, e a cena já dura cerca de dois minutos. Por fim, com as forças esgotadas, ele vira-se para aquela plateia e diz que a surra servirá de "ensinamento" para qualquer um que pensar em passar para o lado do Adeotado (líder dos pelados). Os homens se entreolham, amedrontados. Tidico ainda ordena que joguem sal sobre as feridas dos castigados, e os urros destes ecoam enquanto a câmera traça um movimento vertiginoso sobre a paisagem dos pinheirais, causando náuseas. Um sossego incômodo acompanha a cena seguinte, com a câmera fixa, captando, de longe, o corpo inerte dos três homens nus amarrados no curral.

Tanto na cena dos camponeses pendurados na árvore, quanto nessa passagem da surra, os corpos dos castigados são deixados à mostra, pela sua função exemplar. Mas essas "provas" deveriam ser vistas apenas pelos outros sertanejos, e não pela sociedade civil como um todo. Era um modo de incutir medo nos resistentes e nos seus próprios homens, ameaçando-os à base da violência. Ninguém estará livre do castigo se tentar romper com o poder existente. Trata-se do uso da força para garantir o "vigor" de um indivíduo, numa ordem social em que há combinação de violência e poder, para usar os termos de Hannah Arendt (1994, p. 44).

Na encenação fílmica de Back, os interesses na exploração econômica eram a convicção de uma parte do corpo social, que tinha apoio governamental. Os conflitos de classe tornavam-se gritantes. Num tal contexto, para legitimar a atuação das classes dirigentes diante da opinião pública, uma estratégia atroz foi desenvolvida, atuando simultaneamente em duas frentes: na construção de uma imagem positiva para as autoridades locais e, ao mesmo tempo, na eliminação dos "posseiros" indesejados. 


\section{A violência como aniquilamento}

Para além dessas cenas de coerção, enfim, o filme de Sylvio Back exibe outro tipo de violência, por meio da figuração do holocausto, com a cena dos "enterrados vivos".

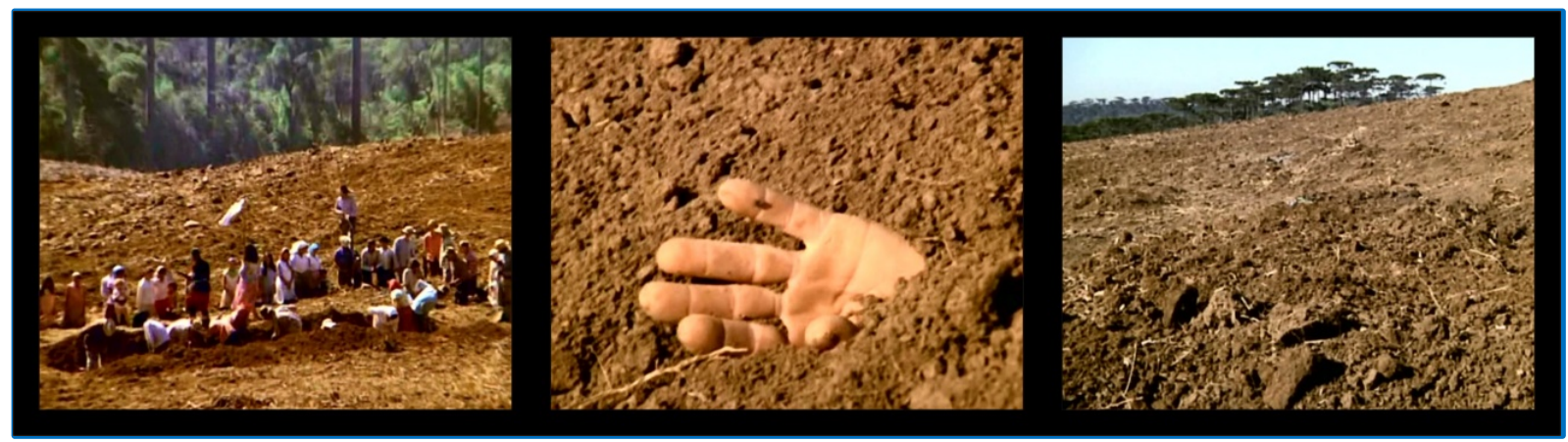

FIGURA 5: Sertanejos são enterrados vivos. A Guerra dos Pelados, 1971.

Uma comunicação oficial é feita via rádio: as autoridades locais dirigem um apelo aos crentes que se acham em companhia de Adeodato. A câmera enquadra uma balsa apinhada de crentes, com seus poucos pertences e suas bandeiras santas, sendo conduzidos por um grupo de soldados armados. Em sobreposição a essa imagem, uma voz no rádio diz: “- Eu os convido para que se retirem para os pontos onde houver forças e civis, aí lhe serão garantidos meios de subsistência, até que o governo lhes dê terra, das quais passará títulos de propriedade"13.

Esse chamado promissor aos camponeses expropriados tornava público, via rádio, que o governo desejava resolver a questão de maneira justa, dando apoio social e doando terras aos crentes, ao mesmo tempo em que reforçava o juízo negativo sobre Adeodato, tido como "subversivo". A notícia se espalharia pelos meios de comunicação, e a imagem das autoridades seria beneficiada por terem supostamente investido em política social. As pessoas na balsa representam a parcela dos camponeses que foram atraídos pelas promessas das autoridades, e acreditam estar sendo levados para a "terra prometida".

Entretanto, o destino que os aguardava era cruel, e logicamente ocultado da opinião pública. As verdadeiras intenções do chamado na rádio foram armar uma "isca"

\footnotetext{
${ }^{13}$ A frase foi transcrita a partir do filme, mas ela é adaptada de um documento oficial distribuído pelo General Setembrino de Carvalho, que comandou a campanha de guerra no Contestado. O documento foi reproduzido pela imprensa em 26 de setembro de 1914, e também publicado Relatório do General Setembrino (CARVALHO, 1915). Está transcrito na íntegra em: MACHADO, 2004, p. 288, nota 67.
} 
para se "livrar do peso morto", como disse um dos caboclos quando percebeu o que estava por acontecer. Após saírem da embarcação, a câmera mostra os pés descalços dos camponeses que caminham por uma roça recém-queimada, numa bela composição visual embalada por melancólica cantiga. Logo depois, a atmosfera da promessa se revela pesadelo. Uns poucos planos mostram quando os crentes recebem ordens para cavar uma grande cova, na qual são jogados vivos e enterrados ${ }^{14}$.

Não há testemunha do assassinato coletivo, apenas nós, espectadores do filme. Aos crentes, diante da morte iminente, não resta outra esperança de justiça que não seja a do olho divino: “- Jagunço! Pensa que o monge não tá vendo?”, mas a resposta que recebem é a agressão física por parte dos soldados.

Dessa vez, a representação dos atos violentos não é explícita como na cena da surra. A câmera não nos fornece a visão das pessoas sendo jogadas na cova, apenas "adivinhamos" o que acontece pelas expressões dos caboclos que aguardam sua vez, e de um dos soldados que executam a violência. Enquanto se ouvem os gritos apavorados, sons de espancamentos e das enxadas investindo sobre a terra, a câmera enquadra em primeiríssimo plano o rosto condoído de uma cabocla, depois o de um soldado e, por fim, a face pesarosa de um velho. O soldado, a certa altura, tapa o rosto com o braço, para não ver o horror, que também não nos é mostrado. Ele exclama: “- Isso é uma covardia!”, e o velho conclui: “- Promessa de peludo é malvadeza de Satanás”.

Os algozes, na situação, são os soldados. Peças na engrenagem do poder, são os executores da violência, mas não os que tomam as decisões - um papel semelhante, pode-se dizer, do que o dos "interrogadores" que faziam uso da violência durante a ditadura $^{15}$. Ao longo do filme, os soldados são seres anônimos quase o tempo todo, agem

\footnotetext{
${ }^{14}$ Um ponto importante a ser notado, aqui, é que os peludos não precisavam dos pelados para se legitimar. Não se trata, portanto, de uma relação de poder, em que $A$ domina $B$, mas precisa do consenso de $B$ quanto ao seu poder. Trata-se, de fato, da mais pura violência, em que $A$ prescinde da presença de $B$, e quer eliminá-lo. É antes um extermínio do que um confronto em que duas forças que pretendem "decidir" uma questão de poder através da violência. Essa "eliminação de seres considerados como definitivamente inúteis" que marca a história do século XX, diz ENRIQUEZ (2001, p. 22) "são uma manifestação da barbárie inerente à razão instrumental".

${ }^{15}$ Segundo Magalhães (2004, p. 202), essa transformação do torturador em "funcionário eficiente" é resultado de um trabalho ideológico, através do qual esse agente "não é tratado como sujeito que pratica o ato violento, mas sim o que coloca em funcionamento os instrumentos de violência". A partir disso, "o sujeito que vitimiza realiza um distanciamento eficaz da vítima - como se entre o ato violento e o seu responsável não existisse qualquer vínculo".
} 

figura, a um só tempo, o dilaceramento e a imobilidade desses que são parte da engrenagem, que são ao mesmo tempo executores e testemunhas silenciosas da face inumana nesse jogo que transborda os limites do poder e adentra o reino da violência. Como tantos, não encontra coragem civil para contrariar o sistema ao qual ele mesmo serve.

Após a representação da atrocidade, um silêncio se instala. Por longos instantes, em dois ou três planos, a câmera apenas focaliza a terra, que pulsa em ritmo de respiração. O acontecido termina em alegoria. Os mortos estão latentes sob a terra que "Ihes foi concedida".

A terra que pulsa, enfim, evoca também os ideais de resistência e de liberdade que permanecem vivos, apesar da repressão. Eliminam-se e escondem-se os corpos, mas as ideias continuam latentes, voltando a se manifestar noutros corpos, noutros tempos e noutros lugares.

\section{A violência como transgressão ao poder instituído}

Na segunda metade do filme, por outro lado, a violência será figurada também como instrumento revolucionário e de luta pela libertação. É o caso das cenas em que os camponeses armados invadem a serraria.

Imediatamente posterior à imagem da terra pulsante, vemos Adeodato liderando os pelados, organizados em piquete, numa ofensiva à serraria da Lumber. É a partir desse momento que o filme dá vigor à faceta revolucionária dos caboclos, ao aderirem à violência para lutar por seus direitos. Até então comedidos em seus atos, haviam sido representados como uma comunidade pacífica, em rituais festivos ou religiosos. Porém, quando a opressão chegou aos limites da tolerância, a figura de Adeodato tomou força, ainda que sem ser heroicizado. Esse personagem significa uma fração de consciência 
política do grupo, convertida em vontade revolucionária. A afirmação da violência agora é posta como única via para a libertação.

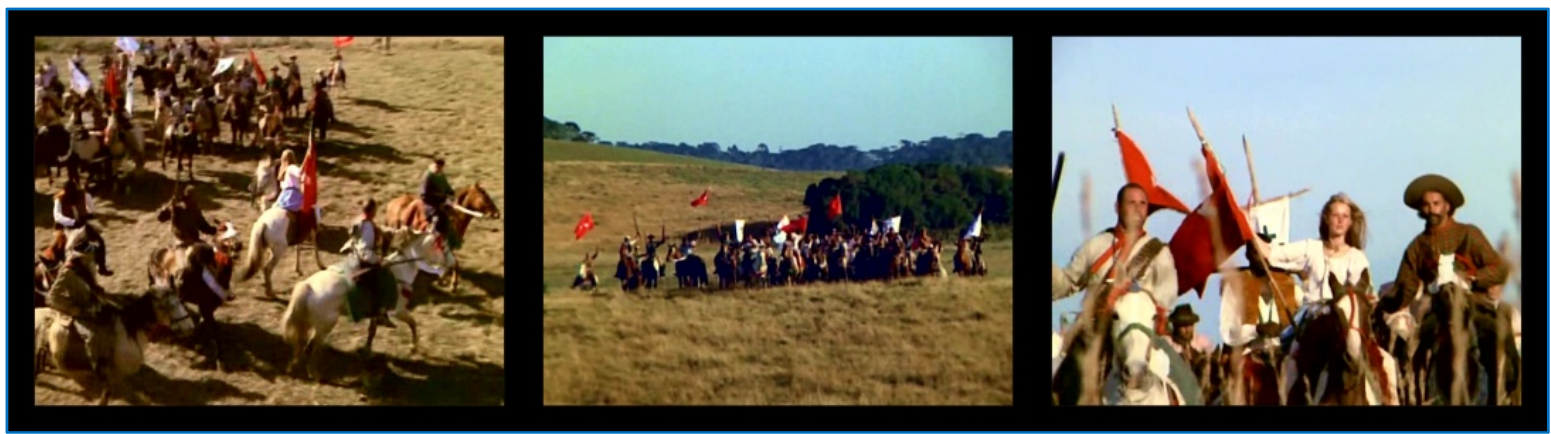

FIGURA 6: Adeodato conclama os pelados ao combate. A Guerra dos Pelados, 1971.

Isso apresenta coerência temática com aquela glorificação da violência por parte dos movimentos de esquerda ao longo dos anos sessenta, antes mencionada, e pautada, em grande parte, na leitura de Sartre e de Franz Fanon em Os condenados da terra, de 1961. Partindo daqueles textos inspirados nos movimentos de libertação anticoloniais, espraiou-se a convicção de que "o homem colonizado liberta-se na e pela violência" (FANON, 1968, p. 66), sendo a luta armada uma via para se emancipar das opressões materiais, políticas e simbólicas nos contextos de repressão: "a violência ergue o povo à altura do líder" ( (FANON, 1968, p. 74).

Fortes ecos dessa onda se fizeram ouvir em território brasileiro, primeiro num sentido alegórico - como a proposição de uma estética agressiva ${ }^{16}$-, mas depois em toda a sua literalidade, alcançando um ponto máximo entre 1968-73, na forma de organizações guerrilheiras urbanas e rurais.

Quanto ao filme de Back, a violência aparece enquanto assunto, na diegese. E, já sabemos, a adesão dos pelados à violência não será garantia de condições melhores. Mas a virada na postura dos sertanejos que se transformam em guerrilheiros afina-se um bocado a essa ideia generalizada entre as esquerdas sessentistas, especialmente quando Adeodato condiciona a conquista de "respeito" à revolta armada, ao incitar os pelados para o ataque à serraria. ${ }^{17}$

\footnotetext{
${ }^{16}$ Sobre as propostas para uma estética da violência no cinema brasileiro, sugiro XAVIER, 2007, p. $183-197$.

${ }^{17}$ Aí também nota-se aproximação com a proclamação de Mao Tsé-Tung (cujas ideias vinham crescendo dentro da Ação Popular desde 1968), de que "o poder brota do cano de uma arma". Segundo Hannah Arendt, trata-se de uma “convicção totalmente não-marxista”. ARENDT, 1994, p. 18.
} 
O piquete sai em cavalgada, e embalado pela música de Sérgio Ricardo atravessa os campos pontilhados de pinheirais. Alguns homens vão armados com espadas de pau ou com rifles e outros carregam bandeiras santas. Empunhando um estandarte vermelho, Ana vai à frente, ao lado de Adeodato, agora atuando enquanto emblema da liberdade. 0 cineasta demora-se na representação plástica dessa tomada de atitude. Ao som do violão e da flauta os revolucionários galopam. A soma de braços erguidos empunhando armas, bandeiras vermelhas e brancas tremeluzentes e o balanço das crinas dos cavalos que galopam, traduz visualmente a animosidade do grupo.

Um corte na imagem nos fornece a vista de um escritório, no interior da serraria, onde trabalha um dos "gringos". No ambiente predominam características europeias. O homem de negócios mantém a feição compenetrada enquanto parece fazer cálculos, atrás de uma escrivaninha, com um cachimbo à boca. Em seguida chegam os sertanejos armados.

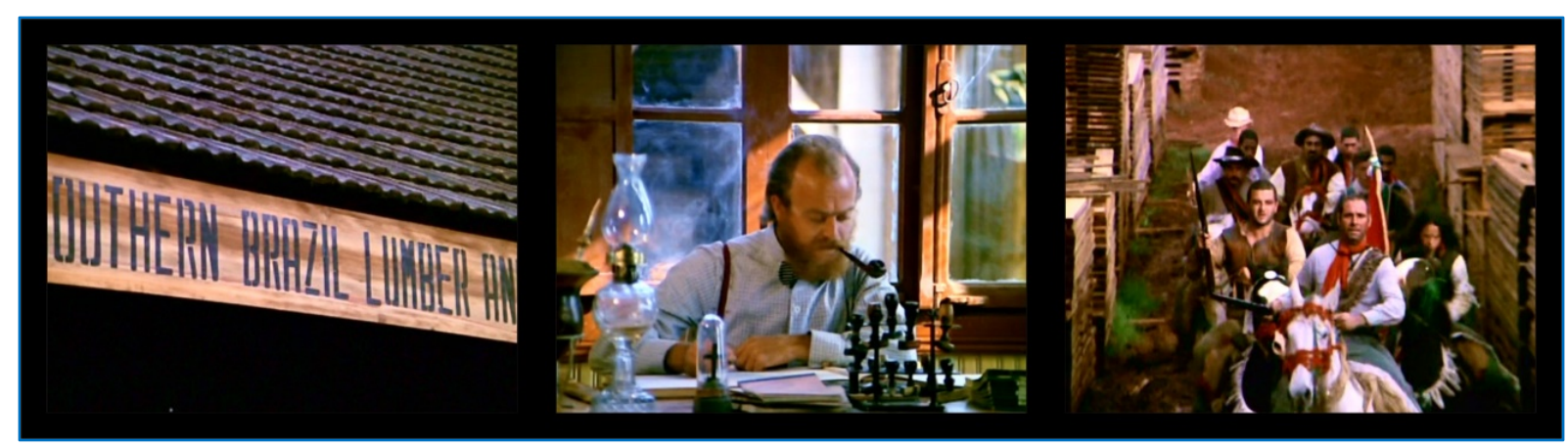

FIGURA 7: A chegada dos rebeldes à serraria. A Guerra dos Pelados, 1971.

Iniciam tiros e quebra-quebra. Os pelados gritam: “- Morram, ladrões de terra!... Morra, gringo!", e invadem o escritório. O homem que fazia contas se levanta, pega um rifle e o aponta para a porta, no instante em que entram os rebeldes. Mas é baleado por Adeodato, que vem à frente. Fica caído ao chão, ferido, enquanto os pelados derrubam mesas, armários, dão tiros em garrafas de bebidas e nos funcionários que ali se encontram. 


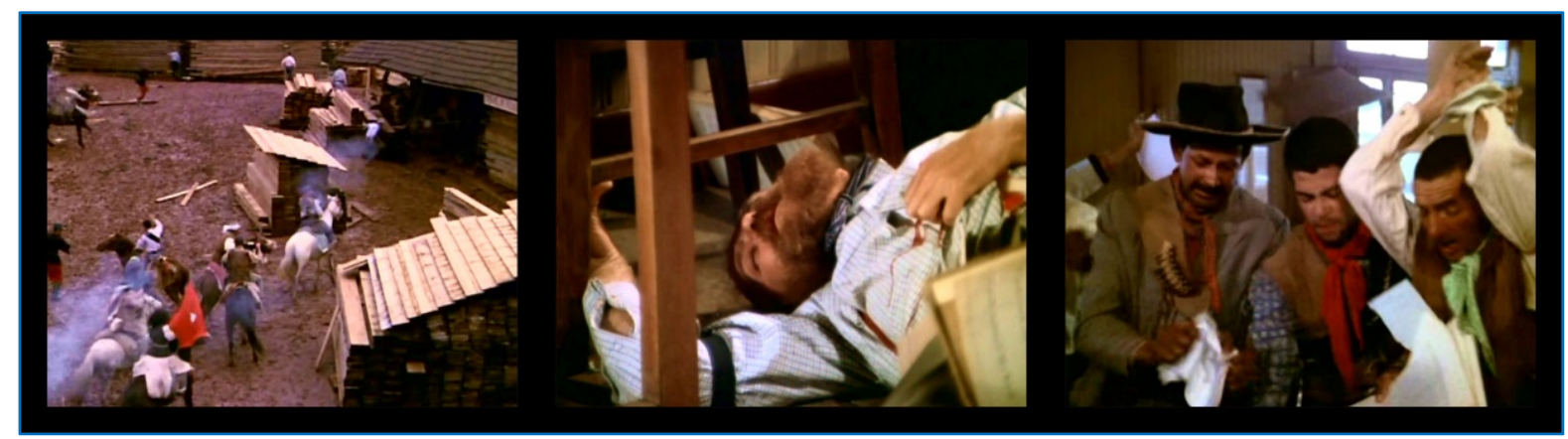

FIGURA 8: Violência e morte no piquete. A Guerra dos Pelados, 1971.

Os pelados remexem nas gavetas e mesas, até encontrar os títulos das terras. Aí, vibram e gritam: “- Chega de pobreza! A terra é nossa!”, ao mesmo tempo em que rasgam e pisoteiam os papéis, chutam os rolos de arame farpado que representam a imposição dos limites territoriais favoráveis à Lumber. À saída, ateiam fogo ao local. Por fim, a câmera focaliza as patas dos cavalos, que pisoteiam a placa com o letreiro da Lumber, agora caída ao chão, quebrada e misturada à lama.

Não é possível deixar de mencionar que esse trecho do filme, como acontecera com a cena da surra, sofreu a ação da censura federal, à época do lançamento. A associação entre exploração estrangeira, luta de classes, disputa pela terra, violência e liberdade, não "caiu bem", pelo visto, naquela conjuntura repressiva. Ambos os momentos que sofreram cortes são pontos fortes dentro do filme, pois justificam, em grande parte, as motivações para o acirramento da guerra. Truncá-los foi também um gesto de violência simbólica.

A opção pela violência, enfim, garantiu uma sobrevida à coletividade dos pelados, mas não os levou à libertação da opressão e nem ao direito à posse da terra que reivindicavam. Por isso, o filme de Back se coloca como olhar incrédulo acerca de quaisquer possibilidades de mudança nas relações de poder já cristalizadas. Como outros eventos que estigmatizaram o século XX enquanto aquele que "conferiu ao domínio do assassinato em massa seu princípio de legitimidade" (ENRIQUEZ, 2001, p. 12), pode-se dizer que os "posseiros fanáticos" que habitavam o sertão catarinense antes da chegada do "progresso" foram literalmente eliminados. 


\section{Memórias de um massacre, memória da resistência}

Nas palavras de Back (Anexo, 1976), a História era o personagem central deste filme. Seu tema mais amplo parecia ser a resistência, sustentada pelo desejo revolucionário. Produzido durante aqueles anos em que as esquerdas brasileiras se armaram para lutar contra a ditadura militar e a imposição da modernização capitalista, ele é, de fato, um filme que elege como assunto a resistência ${ }^{18}$. Mas Sylvio Back impregnou-o de uma incredulidade que se mostra, inclusive, na estruturação da narrativa: não há conquistas por parte dos camponeses que se atiram à revolução. Ao contrário, eles são as vítimas de um massacre. Esse destino já havia sido sinalizado desde a primeira parte do filme, com a morte emblemática do personagem Nenê (Stênio Garcia) que enfrenta o trem de ferro com sua espada de madeira ${ }^{19}$; porém o seu momento de mais intensa afirmação está na segunda parte do filme, com a morte de Pai Velho (Jofre Soares), o líder religioso do grupo de camponeses e emblema máximo do discurso teleológico. Sua morte será a última sequência aqui apresentada.

Pai Velho cumpre um papel muito importante no filme, de preservar entre os personagens um sentido teleológico religioso e, ao mesmo tempo, representar diante do espectador a insustentabilidade de seu próprio discurso. O seu destino, no espaço diegético do filme, é cruel e solitário. Sua morte, que é dramatizada cerca de dez minutos antes do encerramento do filme, sintetiza, na minha opinião, a palavra final do cineasta sobre o sentido do discurso religioso no processo revolucionário social. E representa, além disso, a sua aversão ao modelo de "cinema de redenção".

Ao longo dos trinta minutos finais, A Guerra dos Pelados assume um aspecto mais “descritivo", para usar um termo empregado pela crítica acerca do filme (AZEREDO, 1971; BARROS, 1977). A exceção corresponde justamente às duas sequências que envolvem o discurso salvacionista e a morte do Pai Velho.

\footnotetext{
${ }^{18}$ Resistência é entendida, aqui, como a reação violenta de um grupo de pessoas diante de uma situação insuportável, seja de opressão ou de ataque à sua dignidade. A resistência de um grupo de humanos injustiçado por outro também pode ser traduzida na tentativa violenta de reivindicação dos seus direitos (CABRERA, 2008, p. 152 e p. 155).

${ }^{19}$ Tratei dessa sequência fílmica com mais minúcias em KAMINSKI, 2006.
} 
O discurso redentor do Pai Velho ocorre durante uma investida militar com balas de canhão, que destrói a igreja dos camponeses. Ele conclama todos os fiéis para uma retirada para as terras do município vizinho, tentando incutir-lhes coragem, a exemplo do que fez Moisés conduzindo o povo para a "terra prometida". Há uma alternância de cenas entre o contexto do discurso de pai Velho, que está no alto da torre da igrejinha de madeira falando para todos os fiéis, e os soldados que preparam os canhões para o ataque final, que destrói a igreja, ao mesmo tempo em que ocorre a debandada dos camponeses.

Os pelados se embrenham no mato, alguns levando seus poucos pertences, mulheres carregando crianças. Decidem dividir-se em pequenos grupos para despistar o inimigo. Uns caem, outros ajudam, as bandeiras acabam pisoteadas na lama. O grupo de fugitivos acaba por separar-se e, de repente, Pai Velho está sozinho, carregando a estátua de São Sebastião.

A princípio, a câmera, "escondida" entre as árvores, observa o velho embrenhar-se cada vez mais na mata, e por um tempo o silêncio absoluto cria tensão. Os tiros recomeçam, insistentes, enquanto Pai Velho atravessa um riacho. Após andar algum tempo, ele chama por Adeodato e Ana. Vindo dos arbustos, ouve algo como uma resposta, um “e-ei!” Pergunta: “- ...vocês estão aí?”. A câmera assume o ponto de vista de Pai Velho, aterrorizado. Ela perscruta os arbustos, em travellings laterais, e depois indo adiante, como se fosse o andar do próprio personagem no mato. Os chamados continuam, “e-ei!”, “e-ei!”... A cada vez, a câmera (ocupando o lugar de Pai Velho) se vira na direção do som, movimentos nervosos para um lado, para outro, focando em alguns pontos da vegetação para tentar distinguir quem está ali.

Um novo corte nos dá um plano de conjunto, onde Pai Velho está de perfil. Ele é baleado pelas costas, e grita no mesmo instante em que a câmera se afasta vertiginosamente para trás. À distância, continuamos assistindo o líder religioso ser baleado diversas vezes, até cair, vagarosamente, sangrando pela boca, sem nunca largar a estátua de São Sebastião, que acaba por lhe servir de apoio à cabeça. A estátua perfurada pelas flechas, o velho líder cravejado de balas. O seu próprio sangue escorre sobre a estátua, fundindo-os na ideia de sacrifício da morte pelo credo. Porém, nessa 
cena, ironicamente, a morte de Pai Velho não é testemunhada pelos pares, e não redime ninguém.

Em seguida, os algozes jogam galhos de pinheiro sobre o corpo do velho e da estátua do santo, preparando uma fogueira. O fogo é ateado às grimpas. Mas o que poderia ser o signo final de um ritual de sacrifício, é, na verdade, associado à ideia de “queima de arquivo”. Eliminação dos vestígios, já que ninguém mais presenciou a cena da morte de Pai Velho para poder contestá-la. Ao mesmo tempo em que a cena pode ser interpretada como um lamento pelas atrocidades cometidas nas relações entre os homens, o extermínio de Pai Velho é um atestado do ceticismo do cineasta frente às verdades que se constroem sobre as teleologias - seja a religiosa, seja a política. É a morte da fé.

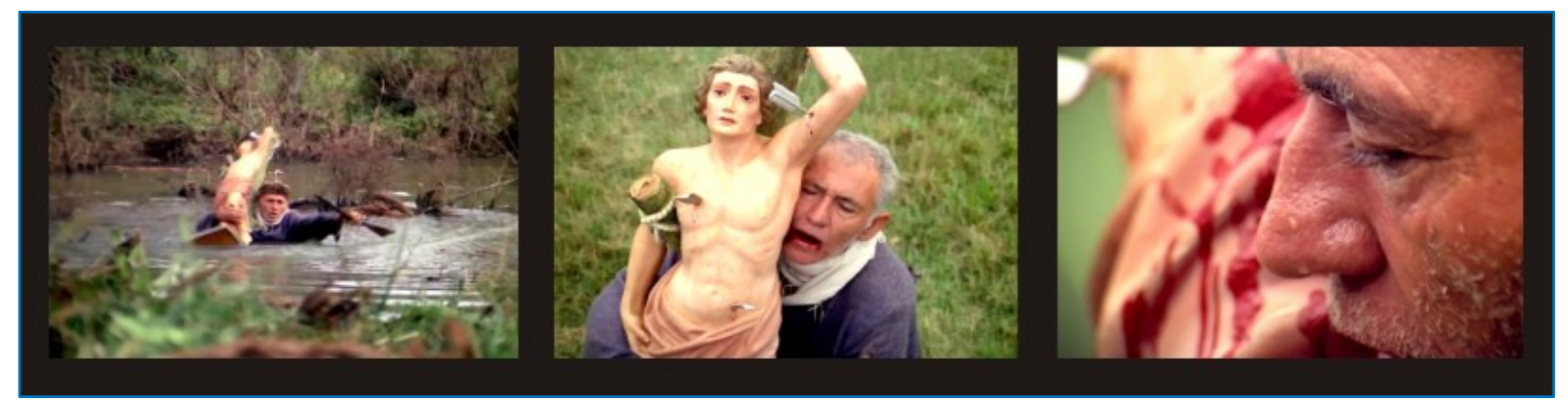

FIGURA 9: Morte do Pai Velho. A Guerra dos Pelados, 1971.

Afora essas duas passagens, durante quase toda essa parte final, a câmera acompanha ora a movimentação dos soldados pela mata - num terreno que lhes é estranho, e no qual enfrentam um inimigo quase "oculto" -, ora as estratégias de ataque dos pelados, cuja organização lembra a das formações guerrilheiras.

Em clara desvantagem em termos numéricos e de armamentos, a resistência dos pelados sustenta-se no conhecimento do território e nas emboscadas. Por exemplo, quando conseguem maior eficiência de cada atirador que se posiciona no alto das araucárias, pois dali têm ampla visibilidade, ao mesmo tempo em que não são vistos com facilidade pelas tropas. Várias tomadas mostram homens que sobem ou descem pelos troncos de araucárias, agarrando-se a eles apenas com os pés e mãos, numa técnica desenvolvida graças ao convívio e integração com a vegetação local. 
Esse tipo de formação guerrilheira representada no filme tem uma correspondência muito direta com seu contexto de produção, visto que entre 1967 e 1969 diversos grupos de esquerda haviam se formado no Brasil, instituindo suas próprias lideranças na defesa pela revolução através da guerrilha, seja no campo ou na cidade, e constituindo o polo mais extremado de resistência à ditadura naquele final de década. O filme foi realizado durante o auge das tensões entre o Estado e os grupos armados, cujos líderes eram caçados pela polícia do Exército $^{20}$. Marighela, por exemplo, líder da Ação Libertadora Nacional e "inimigo da ditadura", havia sido morto numa emboscada preparada pelo conhecido delegado Fleury, no ano de $1969^{21}$. E em 1970, no ano em que aconteceram as filmagens de Pelados, era publicado o Manual da guerrilha urbana, escrito por Marighela em 1969, que dizia ser a guerrilha uma forma subterrânea e imprevista de combate que deveria ser travada segundo "métodos não-convencionais" (MARIGHELLA, 1974) 22.

No filme de Sylvio Back, a resistência realmente possibilitou, no caso dos pelados, uma sobrevida, pois eles combateram bravamente até o fim, com os métodos que lhes estiveram ao alcance. Pode-se entender, assim, o uso da violência no seu sentido revolucionário, conforme abordado por Franz Fanon no livro de 1961, e compreender o filme como uma figuração das potencialidades políticas do uso da violência no tempo presente do cineasta, sob a coloração pessimista do diretor. Enquanto produto daquele momento histórico, o filme constitui uma importante memória desses conflitos que ultrapassavam, em muito, o regionalismo. São memórias dolorosas, mas que ajudaram - e ainda ajudam - a manter o passado ativo no presente.

Tanto a representação da luta armada no filme, quanto a situação política nacional de 1970 são relacionáveis com diversos acontecimentos que se processavam no âmbito internacional. Por exemplo, a existência de outros focos guerrilheiros em países latinoamericanos, inspirados em Che Guevara, e também as táticas adotadas pelos vietnamitas

\footnotetext{
${ }^{20}$ Os líderes dos grupos que defendiam a luta armada eram "caçados" e exterminados. Carlos Marighella, por exemplo, morreu em novembro de 1969 , numa emboscada policial; e Lamarca foi morto no sertão da Bahia em setembro de 1971. Para maiores informações sobre a história da guerrilha brasileira, consultar: CUNHA, 1998; SALTCHUCK, 1995; GORENDER, 1987; e RIDENTI, 2000.

${ }^{21}$ Um relato resumido sobre essa emboscada encontra-se em: GORENDER, 1987, p. 171-178.

22 Publicado pela primeira vez em 1970, com o título Mini-manual of the urban guerrilla, este texto foi usado ao longo dos anos 70 como fonte internacional de literatura guerrilheira.
} 
De acordo com Oscar Milton Volpini (2006), que participou intensamente da realização desse filme ao lado de Back, existiram ao menos dois motivos para essa escolha. Ele diz que, por um lado, Back quis resgatar um aspecto do passado brasileiro que era visivelmente relegado a segundo plano pela historiografia; mas por outro lado, ambos tinham clara intenção de realizar um filme que exemplificasse a resistência do homem simples às formas de exploração e opressão, e cujo sentido fosse a "luta do povo".

No limite, a própria experiência de fazer o filme se transformou numa questão de coragem, exigindo ousadia e certas táticas para burlar os instrumentos de coerção, como era o caso da censura. Apesar de ser incompatível com outras formas de "ação no mundo" que eram propostas naquele momento enquanto oposição civil ao regime, fazer um filme com teor político e dentro das condições disponíveis era, também, uma "ação" que cabia dentro de um conceito ainda mais largo de resistência, se considerarmos, com Napolitano (2004, p. 275), o campo da cultura e das artes enquanto "elementos de recomposição do espaço público esgarçado da política”. Para esse autor, "no plano da memória, o conceito de resistência tem sido suficientemente largo para abarcar as várias formas de 'ação no mundo', os vários 'mundos em comum' que marcaram a rede informal da oposição civil ao regime militar" ( NAPOLITANO, p. 282).

Um filme como A Guerra dos Pelados atua, no limite, como memória de um massacre do qual a historiografia brasileira hesitou lembrar, ao longo de várias décadas, e como memória, ao mesmo tempo, das formas de resistência política do cineasta e de outros agentes culturais ao longo daqueles anos mais duros da ditadura militar. 


\section{Referências}

ANEXO. Diário do Paraná. Curitiba, 24.08.1976.

ARENDT, Hannah. Sobre a violência. Rio de Janeiro: Relume Dumará, 1994.

ARENDT, Hannah. Sobre a revolução. São Paulo: Companhia das Letras, 2011.

AZEREDO, Ely. A guerra dos pelados (II). Jornal do Brasil. Rio de Janeiro, 3 out. 1971.

BACK, Sylvio. Memória I - A estória dos que não estão na história. In: BACK, Sylvio. A Guerra dos Pelados: roteiro do filme. São Paulo: Annablume, 2008.

BACK, Sylvio. Guerra dos Pelados. Panorama, Curitiba, n.361., set., 1986.

BACK, Sylvio. Sylvio BACK: entrevista, Curitiba, 2003. Entrevista concedida à Rosane Kaminski por telefone, em $1^{\circ}$.09.2003.

BARROS, José Tavares de. A Guerra dos Pelados. Diário da Tarde. 25 ago., 1977.

CABRAL, Oswaldo Rodrigues. A Campanha do Contestado. Florianópolis: Editora Lunardelli, 1979.

CABRERA, Julio. Recordando sem ira. In: BACK, Sylvio. A Guerra dos Pelados. São Paulo: Annablume, 2008.

CARVALHO, Fernando Setembrino de. Relatório apresentado ao general José Caetano de Faria, ministro da Guerra, pelo comandante das forças em operações de guerra no Contestado. Rio de Janeiro: Imprensa Militar, 1915.

CUNHA, Maria de Fátima. Eles ousaram lutar: a esquerda e a guerrilha nos anos 60/70. Londrina: Ed. UEL, 1998

DIAS, Reginaldo. Elementos para uma história da Ação Popular no Paraná. Revista de história regional, Ponta Grossa: UEPG, v.4, n.2, inverno 1999.

DUARTE, André. Poder e violência no pensamento político de Hannah Arendt. In: ARENDT, Hannah. Sobre a violência. Rio de Janeiro: Relume Dumará, 1994.

ENRIQUEZ, Eugène. Matar sem remorso: reflexões sobre os assassinatos coletivos. Dossiê: Os lugares da violência. História: Questões \& Debates, Curitiba: Editora da UFPR, n.35, 2001. 
FANON, Franz. Os condenados da terra. Rio de Janeiro: Edição Civilização Brasileira, 1968.

GALLO, Ivone. O Contestado: o sonho do milênio igualitário. Campinas: UNICAMP, 1999.

GORENDER, Jacob. Combate nas trevas: a esquerda brasileira - das ilusões perdidas à luta

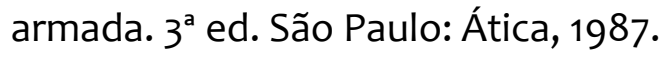

KAMINSKI, Rosane. Da narração literária às telas do cinema: camadas de sentido alegórico em A Guerra dos Pelados (Sylvio Back, 1971). História: Questões \& Debates, Curitiba: Editora UFPR, n.44, 2006.

KAMINSKI, Rosane. Poética da angústia: história e ficção no cinema de Sylvio Back (196070). 2008. Tese (Doutorado em História) - Universidade Federal do Paraná. Curitiba, 2008.

MACHADO, Paulo Pinheiro. Lideranças do Contestado: a formação e a atuação das chefias caboclas (1912-1916). Campinas: UNICAMP, 2004.

MAGALHÃES, Marionilde Brepohl de. Documento: manual do interrogatório. História: Questões \& Debates, Curitiba: Editora UFPR, n.40, 2004.

MARCELINO, Walmor. A guerra camponesa do Contestado. Curitiba: Edição do autor, 1968.

MARCELINO, Walmor. História da AP no Paraná. Curitiba: Quem de Direito, 2005.

MARIGHELLA, Carlos. Manual do guerrilheiro urbano e outros textos. $2^{\mathrm{a}}$ ed. Lisboa: Assírio \& Alvim, 1974.

NAPOLITANO, Marcos. O ‘tesouro perdido': a resistência no campo da cultura (Brasil 1969 / 1976). In: DUARTE, André; LOPREATO, Christina; MAGALHÃES, Marion Brepohl (Orgs.). A banalização da violência: a atualidade do pensamento de Hannah Arendt. Rio de Janeiro: Relume Dumará, 2004.

RAMOS, Alcides. As vicissitudes da relação história-cinema. In: RAMOS, Alcides. Canibalismo dos fracos: cinema e história do Brasil. Bauru: Edusc, 2002.

RIDENTI, Marcelo. Em busca do povo brasileiro. São Paulo: Record, 2000.

RIDENTI, Marcelo. Ação Popular: cristianismo e marxismo. In: RIDENTI, Marcelo; REIS FILHO, Daniel Aarão (Orgs.). História do marxismo no Brasil: vol.V - partidos e organizações dos anos 20 aos 60. Campinas: EdUnicamp, 2002. 
RODRIGUES, Rogério Rosa. Veredas de um grande sertão: a Guerra do Contestado e a modernização do Exército brasileiro na Primeira República. 2008. Tese (Doutorado em História) - UFRJ, Rio de Janeiro, 2008.

QUEIROZ, Maurício Vinhas de. Messianismo e conflito social: a guerra sertaneja do Contestado: 1912-1916. São Paulo: Ática, 1981.

SALTCHUCK, Jaime. Luta armada no Brasil dos anos 60-70. São Paulo: Anita Garibaldi, 1995.

SELIGMANN-SILVA, Márcio (Org.) História, memória, literatura: o testemunho na era das catástrofes. Campinas: Unicamp, 2003.

SELIGMANN-SILVA, Márcio (Org.). A história como trauma. In: SELIGMANN-SILVA, M.; NESTROVSKI, A. (Orgs.). Catástrofe e representação. São Paulo: Escuta, 2000.

SORLIN, Pierre. La storia nei film: interpretazione del passato. Firenze: La Nuova Itália, 1984 .

SORLIN, Pierre. Sociologie du cinéma. Paris: Éditions Aubier Montaigne, 1977.

VOLPINI, Oscar Milton. Oscar Milton Volpini: Entrevista. Curitiba, 2006. Entrevista concedida à Rosane Kaminski. Curitiba, 27 de julho de 2006.

XAVIER, Ismail. Considerações sobre a estética da violência. In: Sertão mar. São Paulo: Cosac Naify, 2007. 